\title{
Sejarah Perkembangan Manajemen Strategi Dukungan Stakeholder
}

\author{
${ }^{1}$ Rintan Wulandari, ${ }^{2}$ Kasfur Anwar US \\ ${ }^{1-2}$ Fakultas Ekonomi dan Bisnis Islam, Universitas Islam Negeri Sulthan Saifuddin Jambi
}

Article history

Received:04-Mei- 2021

Revised: 12-Juni-2021

Accepted:08-July-2021

*Corresponding Author:

Rintan Wulandari,

Kasfur Anwar US

Fakultas Ekonomi dan

Bisnis Islam,

Universitas Islam Negeri

Sulthan Saifuddin Jambi

Email:

Rintanwd30@gmail.com

\begin{abstract}
Abstrak: Manajemen Strategi adalah suatu bidang ilmu yang interdisiplin dan berkembang dengan pesat pada beberapa waktu belakangan ini. Ilmu itu berkembang seiring dengan perkembangan disiplin ilmu lain, seperti pemasaran, mikro, makro, perilaku organisasi, dan banyak lagi. Perkembangan ilmu itu juga sejalan dengan perubahan yang terjadi pada lingkungan, seperti persaingan di industri, perilaku konsumen, dan teknologi. Perusahaan harus dapat mengadaptasi perubahan tersebut bila ingin tetap bertahan dalam bisnisnya. Jika tidak maka akan terlindas oleh perubahan tersebut. Untuk tetap dapat bertahan, banyak konsep yang diperkenalkan oleh para pakar. Artikel ini menerangkan secara singkat konsep utama yang menjadi penyumbang dalam perkembangan ilmu manajemen strategi tersebut.
\end{abstract}

Kata Kunci : Perkembangan, Manajemen Stategi, Dukungan Stakeholder

\section{PENDAHULUAN}

Kemajuan teknologi, perbatasan negara bagian akan runtuh. Demikian pendapat dan penulis Jepang yang mempunyai reputasi internasional, Kenichi Ohmae dan bukunya Akhir BangsaNegara bagian. Pengaruh siaran TV, seperti CNN yang dapat ditangkap dimanamana oleh antena parabola, menyebabkan natipada negara tidak lagi dapat menyensor warga negaranya lihat apa yang terjadi di dunia, bahkan di negaranya sendiri. Beberapa tahun terakhir biaya telepon internasional tidak akan melebihi tarif domestik. Semua orang dapat menggunakan e-mail secara murah. Di lainpihak, berkembang negara pun ramairamai ikut mode untuk menggabungkan diri pada berbagai rencana kawasan perdagangan bebas, seperti AFTA dan APEC. Pada kumpulan ekononomi regional, sama sekali tidak dibayangkan bahwa kedaulatan negara akan dikorbankan atau ditelan oleh suatu berwenang supranasional. Akan tetapi, di Eropa ada gejala, baik ekonomi maupun politik, negara yang bergabung dengan Uni Eropa berangsur-angsumenyerahkan berbagai kepolisianda Brussel yang merupakan pusat pemerintahan dari Uni Eropa. Gejala dunia tanpa batas akan meluas dalam jamaninformasi elektronika dan GATT/WTO pascaputaran Uruguay. Hal tersebtentunya membawa implikasi terhadap dunia bisnis. John Naisbitt menyebut era saat ini sebagai "yang paling menarik dekade". Bagaimana perusahaan berperilaku danmenerapkan strategi bersaing untuk persaingan di era globalisasi mendorong penulis untuk membahas mengenai perkembangan strategi manajemen.

Penulis memulai pembahasan pada evolusi dari strate manajemengi dengan konsep keunggulan bersaing yang diperkenalkan Michael Porter dan bukunya Kompetitif Strategi . Pada awal tahun 1990-an, (Hamel \& Prahalad, 1990) memperkenalkan konsep komptensi inti sebagai faktor penentu bagaimana perusahaan dapat memenangkanpersaingannya. Setelah itu, secara berturut-turut penulis membahas Hypercompetition dari Richard 
D'Aveni dan Strategi Kerajinan dari Henry Mintzberg, dan lain-lain.(Hax \& Majluf, 1984)

\section{METODE PENELITIAN}

Metode penelitian ini menggunakan metode penelitian kualitatif. Sumber data ini berasal dari sumber sekunder, yaitu studi pustaka. Teknik dalam pengambilan data yang digunakan dalam penulisan makalah ini adalah literature review dengan mengumpulkan data dari berbagainsumber referensi. Selain itu, penulis menggunakan literature review dan research article dari jurnal dan pemberitaan online untuk membuat kesimpulan dan evaluasi pada permasalahan yang dikaji. Metode analisis data berupa data sekunder baik berupa data kualitatif maupun kuantitatif dari jurnal dan pemberitaan online. Data sekunder mengacu pada informasi yang dikumpulkan dari sumber yang telah ada, diperoleh dari hasil riset, referensi dan pemberitaan online.

\section{HASIL DAN PEMBAHASAN}

Dalam sebuah organisasi bisnis yang ada terdapat sebuah pihak yang disebut dengan stakeholder. Pihak stakeholder ini merupakan pihak pemangku kepentingan dalam suatu organisasi bisnis yang dapat mempengaruhi atau dipengaruhi oleh tindakan dari bisnis secara keseluruhan.

Konsep stakeholder pertama kali digunakan dalam sebuah memorandum internal 1963 di Stanford Research lembaga. Ini didefinisikan pemangku kepentingan sebagai "kelompok-kelompok yang tanpa dukungan organisasi akan berhenti untuk eksis." Teori ini kemudian dikembangkan dan diperjuangkan oleh R. Edward Freeman pada 1980-an. Sejak itu telah mendapat penerimaan luas dalam praktek bisnis dan teori yang berkaitan dengan manajemen strategis, tata kelola perusahaan, tujuan bisnis dan tanggung jawab sosial perusahaan (CSR). Akan tetapi, kini stakeholder bukan hanya mereka yang berkecimpung dalam organisasi bisnis tersebut. Dalam perkembangannya Stakeholder mencakup pihak-pihak lain yang dibedakan sebagai Stakeholder Internal dan Stakeholder Eksternal.

Dalam kenyataan tersebut muncullah berbagai jenisstakeholder. Namun, dengan pengertian yang telah dituliskan diatas dapat diketahui bahwa seiring dengan berkembangnya zaman, sebuah organisasi bisnis pun mengalami mindset perubahan.Organisasi bisnis secara umum diketahui sebagai sebuah lembaga ataupun institusi yang menyediakan dan memproduksi barang barang serta jasa untuk masyarakat dan bertujuan untuk memperoleh laba bagi perusahaan mereka.

Kini, organisasi bisnis juga memperhatikan isu-isu lain terkait dengan tata kelola perusahaan yang strategis dan efisien serta perhatian terhadap karyawan suatu perusahaan, bahwasannya pimpinan perusahaan kini harus mampu mengelolah perusahaan tidak hanya secara pola kerja yang efektif namun juga harus mampu menciptakan kondisi persaingan sehat antar karyawan di perusahaan tersebut dan tentunya persaingan sehat antar organisasi bisnis lainnya.

Selain itu, organisasi bisnis juga mulai memperhatikan isu-isu sosial yang berkembang dalam masyarakat. Organisasi bisnis memikirkan cara agar prospek bisnis mereka sejatinya dapat membawa pengaruh lain bagi masyarakat. Misalnya saja, saat ini sudah banyak perusahaan yang mengadakan program CSR berbasis kegiatan lingkungan hidup, kesehatan, serta kepedulian terhadap bidang pendidikan.

Stakeholder adalah individu, sekelompok manusia, komunitas atau masyarakat baik secara keseluruhan maupun secara parsial yang memiliki hubungan serta kepentingan terhadap perusahaan. Individu, kelompok, maupun komunitas dan 
masyarakat dapat dikatakan sebagai stakeholder jika memiliki karakteristik seperti yang diungkapkan oleh (Budimanta et al., 2008) yaitu mempunyai kekuasaan, legitimasi, dan kepentingan terhadap perusahaan.

\section{Teori Stakeholder}

'society is a network of voluntary relationships between individuals and organized groups, and strictly speaking there is hardly ever merely one society to which one person exclusively belongs"' (Hayek, 1981).

Pada tahun 1984 terbit sebuah buku karangan R. Edward Freeman yang berjudul "strategic Management: A Stakeholder Approach”(Freeman, 2010). Buku Freeman tersebut dalam waktu relative singkat menarik perhatian para pemikir karena isinya dianggap menggoncangkan paradigma "managerial capitalism" ataupun madzab stategi bisnis yang bertujuan maksimalisasi shareholder value yang dominan saat itu (bahkan masih cukup kuat sampai hari ini). Managerial capitalism adalah sebuah paradigma mengenai penguasaan perusahaan-perusahaan kapitalistis oleh manager.

Managerial capitalsm didefinisikan sebagai perubahan pengelolaan (control) atas perusahaan kapitalis dari pemilik (di era Karl Marx) ke para manajemen eksekutif. Tentu saja undang-undang korporasi yang ruhnya dilahirkan pada era dimana para pemilik (kapitalis) sangat dominan perlu memberikan jaminan bahwa para manajer tersebut bekerja untuk para pemilik. Dalam konteks ini seolah-olah manajemen (dan pemilik) seolah-olah berada dalamsatu kubu menghadapi pihak-pihak lain.

Jelas sekali bahwa beberapa teori, seperti teori keagenan, ataupun beberapa ideologi, seperti kapitalisme dan sosialisme, sangat dipengaruhi oleh paradigma managerial capitalism tersebut. Hal itu terlihat jelas dari peran sentral pemilik (shareholders) dan manajemen dalam menjelaskan fenomena bisnis dan ekonomi di masyarakat.

Hal ini berbeda dengan konsep dalam teori pemangku kepentingan (stakeholder) yang memandang bahwa kelangsungan perusahaan di dalam lingkungan bisnisnya tergantung pada berbagai pihak pemangku kepentingan yang tidak hanya terbatas padapemilik dan manajemen, seperti misalnya pemerinah, karyawan, kreditur, dan konsumen. Institusi tercipta tidak hanya untuk memenuhi kepentingan sendiri melainkan memenuhi kebutuhan macam-macam pihak yang ada disekiarnya. Teori stakeholder paling tidak memiliki tiga pendekatan yang saling terkait: deskriptif, instrumental, dan normatif.

Pendekatan teori deskriptif tersebut menguraikan karakteristik dan perilaku organisasi. Misalnya dalam (Jawahar \& McLaughlin, 2001), kedua peneliti menguraikan peran masing-masing stakeholder pada siklus tahapan bisnis yang berbeda. Pendekatan teori instrumental mencermati data empiris mengenai hubungan antara menejemen kelompok-kelompok kepentingan dengan pencapaian tujuan organisasi. Pendekatan instrumental biasanya bisa dinyatakan dalam kalimat “jika manajemen berperilaku... maka akan berakibat..." pendekatan normatif membahas inti teori serta petunjuk moral etika yang menjadi pedoman manajemen dalam mengelola perusahaan.

Menurut pendekatan ini hungan antara manajemen dengan stakeholder dilandasi oleh komitmen moral (Berman et al., 1999). Klaim kelompok stakeholders tertentu dilandasi atas pandangan etika tertentu yang tidak selalu terkait dengan tata nilai instrumental stakeholders. Artinya, memenuhi klaim yang dilandasi pandangan etika ini tidak selalu menyebabkan tercapainya kepentingan strategis organisasi. 
Beberapa orang menganggap teori pemangku kepentingan bukan 'teori" karena tidak memenuhi syarat sebagai teori, yaitu tidak terdiri dari proposisi yang bisa diuji. Mereka menganggap "teori pemangku kepentingan" sebagai kerangka (framework) dimana dari situ bisa ditarik berbagai pemikiran.

\section{Jenis-Jenis Stakeholder}

Berikut ini terdapat beberapa jenis-jenis stakeholder, antara lain:

1. Stakeholder Utama (primer)

Stakeholder utama merupakan stakeholder yang memiliki kaitan kepentingan secara langsung dengan suatu kebijakan, program, dan proyek. Mereka harus ditempatkan sebagai penentu utama dalam proses pengambilan keputusan.

2. Stakeholder Pendukung (sekunder)

Stakeholder pendukung (sekunder) adalah stakeholder yang tidak memiliki kaitan kepentingan secara langsung terhadap suatu kebijakan, program, dan proyek, tetapi memiliki kepedulian (consern) dan keprihatinan sehingga mereka turut bersuara dan berpengaruh terhadap sikap masyarakat dan keputusan legal pemerintah.

3. Stakeholder Kunci

Stakeholder kunci merupakan stakeholder yang memiliki kewenangan secara legal dalam hal pengambilan keputusan. Stakeholder kunci yang dimaksud adalah unsur eksekutif sesuai levelnya, legisltif, dan instansi. Misalnya, stekholder kunci untuk suatu keputusan untuk suatu proyek level daerah kabupaten.

\section{Peran dan Fungsi Stakeholder}

Peran pihak yang memiliki kepentingan utama atau stakeholder dalam organisasi bisnis ataupun dalam perusahaan, adalah sebagai berikut :

1. Pemilik (owner) atau Pemegang Saham

Pada awalnya suatu bisnis dimulai dari ide seseorang atau lebih tentang suatu barang atau jasa dan mereka mengeluarkan uangnya (modal) untuk membiayai usaha tersebut, karena mereka memiliki keyakinan bahwa kelak dikemudian hari akan mendapatkan imbalan (keuntungan) dan mereka mengorganisasi, mengelola dan menanggung segala resiko bisnis.

2. Karyawan (employee)

Karyawan dalah orang yang diangkat dan ditugaskan untuk menjalankan kegiatan perusahaan. Kinerja perusahaan sangat bergantung pada kinerja seluruh karyawan, baik secara individu maupun secara kelompok.

3. Kreditor (creditor)

Adalah lembaga keuangan atau individu yang memberikan pinjaman kepada perusahaan. Kreditor sebagai pemberi pinjaman, umumnya mengajukan persyaratan tertentu untuk meyakinkan bahwa uang yang mereka pinjamkan kelak akan dapat dikembalikan tepat waktu, sesuai jumlah dan berikut prestasinya.

4. Pemasok (supplier)

Pemasok adalah partner kerja dari perusahaan yang siap memenuhi ketersediaan bahan baku, oleh karena itu kinerja perusahaan juga sebagian tergantung pada kemampuan pemasok dalam mengantarkan bahan baku dengan tepat waktu. Misalnya pemasok kepentingan, jika barang dan jasa yang mereka pasok relative langkah dan sulit untuk memperoleh barang/jasa subtitusi.Kekuatan relatif organisasi terhadap pemangku kepentingan tidak selalu lemah.

5. Pelanggan (customer) 
Dengan mengidentifikasi pelanggan, perusahaan akan lebih fokus dalam memberikan produk dan jasa yang diinginkan dan diharapkan oleh pelanggan mereka. Oleh karena itu perusahaan memiliki kepentingan utama untuk mengidentifikasi individu yang menggunakan produk dan jasa mereka (pelanggan, pesaing dan konsumen).

Suatu perusahaan tidak akan bertahan lama tanpa ada seorang customer. Customer merupakan target dari suatu perusahaan untuk menjualkan hasil produksinya. Untuk menarik seorangcustomer, suatu perusahaan harus menyediakan produk dan layanan yang terbaik serta harga yang bersahabat. Misalnya, suatu oragnisasi dapat memiliki kekuatan yang sangat baik, apalagi jika kondisi pelanggan tidak dapat memperoleh barang/jasa subtitusi yang baik pula.

6. Pesaing

Kesuksesan perusahaan biasanya tergantung pada pengetahuan karyawan tentang pesaing dan peranan mereka dalam bisnis. Bentuk yang paling umum dari pesaing langsung. Pesaing langsung menyediakan produk atau jasa yang sama dalam industri, seperti yang diproduksi oleh perusahaan kita. Sebagai contoh Toyota dan Suzuki, Jatayu Air dan Adam Air adalah pesaing langsung satu sama lain.

7. Pemerintah

Pemerintah misalnya, memiliki kekuasaan untuk memberikan perijinan.Dalam masyarakat yang masih ditandai dengan adanya KKN yang masih kuat, bukan tidak mungkin kekuasaan pemerintah dalam memberikan perijinan dapat mengagalkan semua rencana yang disusun oleh perusahaan.

\section{Kedudukan Stakeholder}

Hasil analisis stakeholders diperoleh kelompok stakeholders :

Promoters : KepentinganBesar, KekuatanBesar.

Defenders : KepentinganBesar, Kekuatan Kecil.

Latents : Kepentingan Kecil, KekuatanBesar.

Apathetics : KepentingandanKekuatan Kecil

\section{Contoh Stakeholder}

\section{Pelanggaran Etika Bisnis oleh Oreo PT. Nabisco}

Segmentasi PT. Nabisco pun tepat dalam mengeluarkan produk biskiut coklat berlapiskan susu ini. Namun biskuit oreo yang merupakan biskuit favorit anak-anak mengandung bahan melamin. Dalam kasus Oreo sengaja menambahkan zat melamin padahal bila dilihat dari segi kesehatan manusia, zat tersebut dapat menimbulkan kanker hati dan lambung. BPOM dan dinas kesehatan mengatakan bahwa oreo produksi luar negri mengandung melamin dan tidak layak untuk dikonsumsi karna berbahaya bagi kesehatan maka harus ditarik dari peredarannya. Pembersihan nama oreo pun sebagai biskuit berbahaya cukup menguras tenaga bagi public relation PT. Nabisco.

\section{Mempelajari Dokumen Perusahaan}

Pada tahapan ini dilakukan studi dokumen perusahaan yang relevan untuk mendapatkan inputan yang akan digunakan pada tahapan berikutnya. Dokumen perusahaan yang dapat digunakan adalah struktur tim program implementasi ERP, struktur organisasi perusahaan PTPN XI, dan job description.

\section{Membuat Strategi Manajemen Stakeholder}

Pada tahapan ini tiap stakeholder akan dibuatkan rencana strategi manajemen terkait bagaimana PMO harus memperlakukan stakeholder sesuai dengan power dan 
interest nya.

\section{Melakukan Validasi Strategi Manajemen Stakeholder}

Strategi yang telah dibuat perlu dilvalidasi oleh pihak PT Perkebunan Nusantara XI. Validasi ini berguna untuk melakukan pengecekan apakah strategi manajemen yang dibuat sudah paling sesuai dengan power dan interest dari tiap stakeholder.

\section{Analisa dan Hasil}

Analisis dilakukan sesuai dengan metodolodi pada bagian sebelumnya. Hasil dan pembahasan akan disajikan berdasarkan urutan aktivitas pada metodologi.

\section{Matrix Power/ Interest}

Matrix power/interest merupakan bentuk visualisasi dari penilaian interest dan power yang telah dilakukan sebelumnya. Berikut ini adalah matrix power/interest stakeholder program implementasi ERP di PTPN XI.

Matrix power/interest membagi stakeholder ke dalam empat kuadran, yaitu Key

Players, Keep Informed, Keep Satisfied, dan Minimal Effort. Dari hasil pengelompokkan, didapatkan kesimpulan masing-masing kuadran sebagai berikut:

Key Players menggambarkan kelompok yang berisi stakeholder yang sangat dibutuhkan dukungannya. Key Players merupakan stakeholder yang biasanya terlibat di dalam aktivitas yang membutuhkan keputusan penting.

1. Keep Informed merupakan kelompok stakeholder yang perlu PMO selalu beri informasi mengenai perkembangan proyek atau sebagainya.

2. Keep Satisfied adalah kelompok yang sebaiknya mendapatkan informasi terkait proyek supaya mereka tetap merasa puas (satisfied). Stakeholder pada kelompok ini harus dikelola sebagaimana mungkin supaya mereka tidak menghambat jalannya proyek.

3. Minimal Effort adalah kelompok stakeholder yang tingkat power dan dedikasinya lebih rendah dari kelompok lain.

\section{Strategic Management}

1. Strategic planning tidak akan berguna bila tidak ada dukungan, masukan, dan komitmen dari lower level manager.

2. Planning harus terintegrasi dengan sistem administrasi yang ada di perusahaan, seperti management control, komunikasi dan informasi, serta motivasi dan rewards.

3. Sistem adminstrasi dan struktur organisasi harus dapat dikoordinasikan dengan baik dengan culture (budaya) dari perusahaan.

\section{Perencanaan Strategis Bisnis}

1. Tahun 60-an terjadi peruba han lingkungan yang penting di Amerika Serikat, yaitu pertumbuhan yang terus menuitidak dan tingkat persaingan di beberapa kunci industri Amerika.

2. Bergesernya fokus perhatian manajerial dari produksi ke pemasaran. 3.peningkatan pada diversifi kasi yang dilakukan beberapa perusahaan penting melalui proses akuisisi yang agresif. 
3. Munculnya konsep Segmentasi Bisnis, membagi-bagi bisnis dalam suatu unit atau entitas tertentu yang independenn dan otonom, entitas tersebut yang sekarang dikenal dengan Unit Bisnis Strategis (SBU).

4. Dengan melengkapi SBU itu, memungkinkan manajer secara bebasol bisnis yang dibawahinya, bebas menentukan strategi yang tepat, memiliki konsumen tertentu, pesaing tertentu, tidak harus tergantung dengan bisnis (SBU) lainnya 6.Munculnya Pendekatan Portofolio Bisnisch model yang digunakan seperti diketahui sekarang ini, yaitu Boston Consulting Group Approach (BCG) dan General Electric (GE) Pendekatan.

5. Mulai diperkenalkan dan digunakannya konsep analisis persmodel dari Porter.

\section{Perencanaan Strategis Perusahaan}

1. Perkembangan di bidang elektronik dampak dampak perubahan yang pesat di sisi teknologi.

2. Bisnis dari perusahaan berhadapan dengan pesaing baru yaitu Jepang yang menjadi pesaing terkuat bagi mereka. Hal itu membuat persaingan menjadi semakin ketat dan sengit.

3. Proyeksi pada pasar internasional dikarenakan adanya ketidakpastian (ketidakpastian). Penyebabnya adalah inflasi, nilai tukar mata uang asing, dan kondisi perekonomian negara yang berbeda-beda di seluruh dunia

4. Ketidakpastian muncul juga disebabkan oleh pe rilaku yang lebih tegas dari kelompok tertentu dalam masyarakat yang menuntut perhatian yang lebih besar dari perusahaan terhadap lingkungan sekitarnya. Kelompok tersebut adalah pemangkukepentingan. Stakehoders bukan hanya terdiri dari pemegang saham, kreditur, klien, pemasok, pengelola dan karyawan saja tetapi juga pemerintah, masyarakat, kon aktivis lingkungan hidup, dan lain sebagainya.

5. Tekanan lingkungan eksternal memaksa perusahaan untuk mempertimbangkan kembali kebijakan alokasi atau pembagiansumber daya, jaringan distribusi, Tenaga penjualan, dan lainnya) yadimiliki oleh masing-masing msatu SBU. Pertimbangannya pada pengurangan biaya dan peningkatan efisiensi untuk mengalahkan pesaing.

\section{Ancaman Masuknya Pendatang Baru}

Pendatang baru yang masuk ke dalam industri dapat menyebabkan intensitas persaingan meningkat. Besar kecilnya ancaman tersebut ditentukan oleh ada tidaknya hambatan bagi pendatang baru untuk memasuki industri. Besar kecilnya hambatan masuk, antara lain ditentukan oleh hal berikut.

a. Skala ekonomi

b. Diferensiasi produk

c. Capital requirement

d. Switching cost

e. Akses ke saluran distribusi

f. Kebijakan pemerintah

\section{Tingkat Rivalitas di Antara Pesaing yang Ada}

Tingkat rivalitas di antara pesaing merupakan upaya masing-masing pesaing 
memenangkan persaingan melalui penerapan strategi harga, promosi, peningkatan kualitas pelayanan, dan lain-lain. Intensitas persaingan antarperusahaan ditentukan oleh beberapa faktor, seperti berikut ini.

a. Adanya beberapa pesaing yang seimbang.

b. Perumbuhan industri yang lambat.

c. Kurangnya diferensiasi atau switching cost.

d. Pertambahan kapasitas yang tinggi.

e. Hambatan pengunduran diri yang tinggi.

\section{Tekanan dari Produk Pengganti}

Produk pengganti adalah suatu produk yang fungsinya dapat menggantikan fungsi produk suatu industri. Besar kecilnya ancaman produk pengganti tergantung dari tingkat harga dan kualitas produk pengganti dibandingkan dengan produk suatu industri.

\section{Kekuatan Tawar Menawar Pembeli}

Kekuatan tawar menawar pembeli akan besar jika terjadi hal berikut.

a. Pembeli membeli dalam jumlah besar.

b. Produk yang dibeli adalah produk standar dan tidak terdiferensiasi.

c. Pembeli memperoleh benefit yang rendah.

d. Produk industri bukan merupakan produk yang terlalu dibutuhkan oleh pembeli, seperti barang mewah.

e. Pembeli menempatkan suatu ancaman melakukan backward integration untuk membuat produk industri.

Kekuatan Tawar Menawar Pemasok

Kekuatan tawar menawar pemasok ditentukan oleh hal berikut.

a. Industri pemasok didominasi oleh sedikit perusahaan.

b. Produk pemasok merupakn produk unik.

c. Industri tersebut bukan merupakan pelanggan penting bagi pemasok.

d. Pemasok meperlihatkan ancaman untuk melakukan forward integration.

\section{Melihat Pandangan Baru Tentang Strategi}

Dasar pemikiran Prahald sederhana saja, persaingan meraih masa depan adalah persaingan untuk menciptakan dan mendominasi peluang yang muncul, memperebutkan ruang bersaing yang baru. Menciptakan masa depan lebih menantang dibandingkan mengejar ketertinggalan karena kita harus membuat sendiri peta jalan kita. Tujuannya bukan sekedar meniru produk dan proses pesaing serta meniru metodenya, melainkan mengembangkan titik pandang yang independen tentang peluang masa depan dan bagaimana memanfaatkannya. Menciptkan jalur (path breaking) jauh lebih menguntungkan dibandingkan mematok duga (bench marking). Orang tidak mungkin tiba paling dulu di masa depan dengan membiarkan orang lain menjadi perintis.

Tersirat adalah arsitektur strategik yang memberikan cetak biru untuk membangun kompetensi yang diperlukan untuk mendominasi pasar masa depan. Dengan pandangan baru tersebut, tidak perlu memikirkan ketidakcocokan antara tujuan dan sumber daya tetapi lebih mementingkan penciptaan tujuan abadi (stretch goals) yang menantang para karyawan untuk mencapai apa yang nampaknya tidak mungkin. Strategi adalah upaya untuk mengatasi kendala sumber daya melakui kegiatan kreatif tanpa akhir untuk mendapatkan resource leverage yang lebih baik. 


\section{Cara Baru Melihat Keungulan Bersaing}

Melihat keunggulan bersaing dengan cara baru adalah dalam pandangan yang dinamis. Dalam pandangan tersebut, ada beberapa ketentuan yang berlaku.

1. Setiap keunggulan akan mengalami erosi. Hal itu berarti bahwa keungglan bersaing tidak akan tetap bertahan sebagai suatainable competitive advantage. Cepat atau lambat, pesaing akan meniru atau bahkan mengatasi keunggulan yang sudah dimiliki terebut. Bila hal tersebut terjadi maka keunggulan itu tidak akan berarti apa-apa lagi.

2. Membuat keunggulan bertahan lama berarti bunuh diri. Berusaha mempertahankan keunggualn bersaing yang dimiliki, menurut D'Qveni berarti memberi kesempatan kepada pesaing untuk emperkuat diari dan mendapatkan keunggulan baru.(D’Aveni \& Robert, 1994)

3. Tujuannya ialah meruntuhkan, bukan membuat sustainable competitive advantage. Dalam situasi hypercompetition, tujuan utama strategi adalah meruntuhkan status quo dan mengambil inisiatif dengan menciptkan sederetan temporary competitive advantage. Dengan cara tersebut, perusahaan akan selalu selangkah di depan dibandingkan dengan para pesaingnya, bergerak dari satu keunggulan ke keunggulan yang baru.

4. Mengambil inisiatif dengan langkah kecil. Karena siklus persaingan semakin pendek, kebutuhan untuk mendapatkan keunggulan baru dengan cepat menjadi meningkat. Dengan demikian, tidak mungkin lagi memikirkan strategi untuk lima atau sepuluh tahun ke depan. Hal yang dibutuhkan adalah serentetan langkah pendek yang akan diambil berurutan.

\section{Cara Lama Melihat Keunggulan Bersaing}

Cara lama melihat keunggulan bersaing, menurut D’Aveni, adalah persaingan berada dalam situasi relatif statis.(D'Aveni \& Robert, 1994) Keunggulan bersaing dalam situasi statis tersebut, diperoleh dari keberhasilan dalam empat arena kunci persaingan sebagai berikut.

1. Harga dan Kualitas (Price and Quality)

Pandangan yang paling sederhana tentang keunggulan bersaing adalah perusahaan bersaing dengan harga atau dengan kualitas barang. Dengan harga rendah diharapkan penjualan meningkat dan biaya tetap dapat dialokasikan pada volume penjualan yang besar. Harga rendah tersbut hanya mungkin jika biaya produksi juga rendah dan hal tersbut dapat dilakukan menggunakan konsep Porter Overall Cost Leadership. Dengan harga yang tinggi diharapkan dapat diperoleh margin yang tinggi dengan kualitas yang tinggi. Hal tersebut dapat dilakukan dengan konsep Porter Product Differentiation. Dalam pandangan itu, keunggulan yang dimiliki, baik berupa harga maupun kualitas, dapat bertahan lama dengan upaya tertentu. Akan tetapi, dalam pandangan yang lebih dinamis, kunggulan yang diperoleh, baik dengan harga maupun kualitas, tidak akan bertahan lama. Pesaing akan muncul dengan produk yang berkualitas atau dengan harga yang lebih rendah.

2. Waktu dan Pengetahuan (Time dan Know-How)

Arena persaingan kedua adalah dengan memasuki pasar lebih dulu dari pesaing dan 
dengan penguasaan teknologi. Dalam pandangan yang statis, keunggulan itu juga dapat dipertahankan dalam jangka waktu cukup lama. Namun, dalam pandangan yang lebih dinamis tentang keunggulan bersaing, masing-masing pesaing akan berusaha terlebih dahulu dalam memasuki pasar dengan menguasai teknologi untuk inovasi produk.

3. Daerah Kekuasaan (Strongholds)

Arena persaingan ketiga untuk mendapatkan keunggulan bersaing dalam pandangan statis adalah dengan membatasi jumlah pesaing dalam daerah kekuasaan tertentu dengan menciptakan Barrier to Entry. Dengan jumlah pesaing yang sedikit, masingmasing akan menikmati laba besar dan situasi itu akan bertahan selama Barriers to Entry dapat dipertahankan. Dalam pandangan yang lebih dinamis tentang keunggulan bersaing, Barriers to Entry pada akhirnya akan runtuh karena pesaing yang ingin masuk akan melakukan segalah upaya untuk mengatasi rintangan tersebut.

4. Dompet Tebal (Deep Pocket)

Arena persaingan keempat adalah menggunakan sumber daya yang lebih besar. Dengan banyaknya sumber daya yang digunakan, perusahaan akan memiliki kapasitas bersaing lebih besar. Akan tetapi, dalam pandangan yang lebih dinamis, keunggulan tersebut akan hilang bila beberapa pesaing membentuk aliansi untuk menghadapi perusahaan yang memiliki sumber daya lebih besar.

Pandangan dinamis tentang keunggulan bersaing, menurut D'Aveni didasarkan pada tiga prinsip dasar berikut. (D’Aveni \& Robert, 1994)

1. Interaksi Strategis yang Dinamis

Prinsip pertama, bahwa dalam strategi bersaing, semua aksi sebenarnya adalah interaksi. Setiap langkah strategis yang diambil perusahaan sebenarnya adalah counte rmove atau sebagai antisipasi terhadap langkah pesaing. Dalam setiap interaksi yang dinamis, suatu perusahaan yang mengambil langkah untuk mendapatkan keunggulan sementara akan segera dibalas oleh pesaing untuk menetralisasi persaingan atau mendapatkan keunggulan baru. Perusahaan pertama akan terpaksa mengambil tindakan balasan lagi dan situasi itu akan terus berlanjut sehingga situasi persaingan dalam industri tersebut akan menjadi lebih ketat.

2. Strategi adalah Relatif

Prinsip kedua yang mendasari pandangan baru tengang keunggulan bersaing adalah bahwa tidak ada strategi yang mutlak, semuanya relatif. Posisi persaingan suatu perusahaan serta ketahanan keunggulan yang dimilikinya selalu dilihat dalam hubungannya dengan pesaing. Posisi perusahaan A dikatakan kuat sebagai low cost producer, kalah semua pesaing berada pada posisi yang lebih lemah. Artinya, biaya mereka lebih tinggi daripada perusahaan A. Begitu pula dalam hal ketahanan keunggulan yang dimiliki suatu perusahaan, hal itu dilihat dari reaksi pesaing terhadap keunggulan tersebut.

3. Kecendrungan dalam Empat Arena Persaingan

Prinsip ketiga adalah posisi strategis suatu perusahan tidak hanya relatif terhadap para pesaing tetapi juga dilihat dalam konteks sejarah interaksi yang dilakukan oleh pesaing. Oleh sebab itu, pesaing harus memproyeksikan kecendrungan jangka panjang untuk memahami ke mana arah persaingan tersebut. Keempat arena persaingan yang diuraikan menyediakan suatu kerangka yang berguna untuk menelusuri interaksi strategis yang dinamis antara pesaing dalam jangka waktu yang panjang dan untuk memahami evolusi industri. 


\section{Perubahan Pandangan terhadap Segmentasi Bisnis}

Muncul dilema bagaimana caranya agar ada kesesuaian dan konsistensi antara fokus strategi untuk segmen pasar yang berbeda dengan struktur organisasi fungsional. Untuk itu, harus dibentuk suatu kelompok dalam struktur organisasi yang dapat menjembatani antara struktur dan strategi. Interrelationship antara satu SBU dengan SBU lainnya, yaitu shared resources dan shared concerns. Digunakannya konsep value-added chain untuk mengidentifikasi shared resources dan shared concerns. Dalam proses corporate strategic planning terdapat tiga level hierarki dari planning sebagai berikut.
a. Corporate level
b. Business level
c. Functional level
d. Corporate Strategic Planning Process
e. The Vision of the firm: corporate philosophy, mission of the firm and identification of SBUs and their interactions.
f. Strategic posture and planning guidelines: corporate strategic thrust, corporate
g. performance objectives and planning challenge.
$h$. The mission of the business: business scope and identification of products market segments.
i. Formulation of business strategy and broad action programs.
j. Formulation of functional strategy.
$k$. Consolidation of business and functional strategies.
l. Definition and evaluation of specific action program at the business level.
$m$. Definition and evaluation of specific action program at the functional level.
$n$. Resources allocation and definition of performance measurements fo management control.
o. Budgeting at business level.
p. Budgeting at functional level.
q. Budgeting consolidations and approval of strategic and operational funds.

\section{KESIMPULAN}

Globalisasi ekonomi membawa pengaruh yang sangat pesat. Dalam memasuki abad ke-21, ekonomi dunia sedang menghadapi realitas baru. Struktur dunia mengalami pergeseran yang intensif sejak beberapa tahun yang lalu. Tren tersebut mempengeruhi perkembangan manajemen strategi dengan rincian sebagai berikut.

1. Industri menjadi semakin mengglobal sehingga bersifat dinamis dan move strategy pemain global menjadi semakin intensif sehingga kondisi pasar makin ditandari hypercompetition.

2. Tiap keunggulan kompetitif menjadi bersifat sementara sehingga perusahaan dipaksa untuk meningkatkan kemampuan yang tidak bersifat fit dengan eksternal tetapi mentransformasikan terus menerus seluruh aspek manajemen internal agar selalu relevan dengan kondisi persaingan baru.

\section{DAFTAR PUSTAKA}

Berman, S. L., Wicks, A. C., Kotha, S., \& Jones, T. M. (1999). Does stakeholder orientation matter? The relationship between stakeholder management models and firm financial performance. Academy of Management Journal, 42(5), 488-506. 
Budimanta, A., Prasetijo, A., \& Rudito, B. (2008). Corporate Social Responsibility: Alternatif Bagi Pembangunan Indonesia. Jakarta: ICSD.

D’Aveni, A., \& Robert, G. (1994). Hypercompetition: Managing Dynamic of Strategic Maneuvering. New York: The Free.

Freeman, R. E. (2010). Strategic management: A stakeholder approach. Cambridge university press.

Hamel, G., \& Prahalad, C. K. (1990). The core competence of the corporation. Harvard Business Review, 68(3), 79-91.

Hax, A. C., \& Majluf, N. S. (1984). Strategic management: an integrative perspective. In Strategic management: An integrative perspective (p. 468).

Hayek, F. A. (1981). Kinds of order in society. Institute for human studies.

Jawahar, I. M., \& McLaughlin, G. L. (2001). Toward a descriptive stakeholder theory: An organizational life cycle approach. Academy of Management Review, 26(3), 397-414. 